\title{
Histochemical Studies on a Ceroid-like Pigment Accompanied by an Increase of Glycogen Contents in the Liver of Mice
}

\author{
Tatuji Hagmara, Reiko Takada, Ichiro Yamagata and Emyo Nakano \\ (Director : Prof. R. Maeda) \\ Pathological Institute, Kansai Medical School, Moriguchi, Osaka
}

It has been demonstrated ${ }^{6)}$ that the ceroid pigment which had been reported by Lillie and others $(1941)^{3)}$ was also existent physiologically in the animal adrenal cortex and human ovarian stroma. During the present experiments it was found that a ceroid-like pigment developed in mouse Kupffer's cells under a condition different from vitamin $\mathrm{E}$ deficiency", i.e., following subcutaneous administration of sodium silicate, sodium silicate plus prednisolone, sodium nucleate plus prednisolone. It was interesting that such a development, having never been reported, had been encountered through experiments adopted for the production of amyloid.

\section{Materials and Methods}

Twenty-three adult mice were used for the experiments. They were divided into Group I which was subjected to subcutaneous administration of $0.1 \mathrm{cc}$ of $0.2 \%$ sodium silicate once a week, Group II which consisted of Group I plus $1 \mathrm{mg}$ of prednisolone subcutaneously administered subsequently every other day, and Group III which received $15 \mathrm{mg}$ of sodium nucleate subcutaneously every day followed by $1 \mathrm{mg}$ of prednisolone four to eight times every other day (Table 1). There were also employed four mice which had been fed on a vitamin $E$ deficient diet, five control mice, and three adult rats in fasting, the last ones being employed for lipofuscin test. The livers of the above group animals were fixed in $10 \%$ neutral formalin and in pure alcohol, made into routine paraffin sections, and studied on various histochemical methods (Table II).

\section{Results}

In the Kupffer's cell or histiocyte in Group I, II, and III, there developed a pigment resembling the ceroid pigment which was observed in the liver of mice fed on a vitamin $\mathrm{E}$ deficient diet. Histochemically this ceroid-like pigment is primarily yellow and less sudanophilic than the ceroid pigment. It proved PAS-positive itself as well as following a treatment with saliva, and Mallorypositive as well as acid fast fuchsin-positive. It is chrome alum hematoxylin negative as is the case with the ceroid pigment. It shows results almost similar to the ceroid pigment following reductive tests including Masson's am- 
moniacal silver method but is M-Nadi reaction negative unlike the ceroid pigment. The ceroid pigment is intensely stained with basophile dyes such as methylgreen and toluidine blue, while a ceroid-like pigment is scarcely stained with them. The 2-hydroxy-3-naphthoic acid hydrazide-naphthanil diazo blue B method is positive. The frequency of development of a ceroid-like pigment is shown in table 3. It was very interesting that a marked increase of glycogen is observed in the liver cells of all the tested groups.

Table 1

\begin{tabular}{|c|c|c|c|c|}
\hline $\begin{array}{c}\text { Experimental } \\
\text { groups }\end{array}$ & $\begin{array}{l}\text { No. of } \\
\text { mice }\end{array}$ & $\begin{array}{l}\text { Weigh } \\
\text { (g) }\end{array}$ & $\begin{array}{l}0.2 \% \text { sodium } \\
\text { silicate, } 0.1 \mathrm{cc} \\
\text { once a week }\end{array}$ & $\begin{array}{c}\text { Prednisolone, } \\
1 \mathrm{mg} \text { every } \\
\text { other day }\end{array}$ \\
\hline I & 4 & 33 & 10 & \\
\hline II & 6 & 30 & 20 & 4 \\
\hline $\begin{array}{c}\text { Experimental } \\
\text { groups }\end{array}$ & $\begin{array}{l}\text { No. of } \\
\text { mice }\end{array}$ & $\begin{array}{l}\text { Weigh } \\
(\mathrm{g})\end{array}$ & $\begin{array}{l}\text { Sodium nucleate } \\
15 \mathrm{mg} \text { daily }\end{array}$ & $\begin{array}{c}\text { Prednisolone, } \\
1 \mathrm{mg} \text { every } \\
\text { other day }\end{array}$ \\
\hline \multirow[t]{4}{*}{ III } & 2 & 25 & 30 & 4 \\
\hline & 2 & 30 & 30 & 8 \\
\hline & 2 & 25 & 45 & 4 \\
\hline & 2 & 23 & 45 & 8 \\
\hline
\end{tabular}

Table 2

\begin{tabular}{l|cc}
\hline \multicolumn{1}{c}{ Methods } & $\begin{array}{c}\text { Ceroid-like } \\
\text { pigment }\end{array}$ & $\begin{array}{c}\text { Ceroid } \\
\text { pigment }\end{array}$ \\
\hline Hematoxylin and eosin stain & Yellow & Yellowish brown \\
Sudan III stain on paraffin section & + & + \\
PAS reaction & + & + \\
Treatment with saliva, followed by PAS reaction & + & + \\
Mallory's hemofuschin method & + & + \\
Acid fast fuchsin stain & + & + \\
The alkaline blue tetrazolium reaction & + & + \\
Masson's ammoniacal silver method & + & + \\
Schmorl's method & \pm & + \\
M-nadi reaction & - & + \\
Performic acid Schiff reaction & + & - \\
2-hydroxy-3-naphthoid acid hydrazide-naphthanil & + & + \\
diazo blue B method & - & + \\
Chrome alum hematxylin method & + & + \\
Luxol fast blue B method & + & + \\
Alcian blue method & + & + \\
Methylgreen stain & + & + \\
Azur A stain & - & + \\
Toluidine blue stain & - & + \\
Treatment wich KMnO, followed by nile blue stain & - & + \\
Mayer's methyl violet method for amyloid & + & + \\
Perls-Stieda's reaction for iron & & + \\
\hline
\end{tabular}


Table 3

\begin{tabular}{|c|c|c|c|c|c|}
\hline \multirow{2}{*}{\multicolumn{2}{|c|}{ Experimental groups }} & \multirow{2}{*}{ Glycogen } & \multicolumn{3}{|c|}{ Ceroid-like pigment } \\
\hline & & & Ht & H & + \\
\hline I & Sodium silicate & + & & 1 & 2 \\
\hline II & Sodium silicate plus prednisolone & Ht & 4 & 1 & 1 \\
\hline III & Sodium nucleate plus prednisolone & tit & 1 & 3 & 4 \\
\hline & Vitamin E deficient diet group & \pm & $\begin{array}{c}2 \\
\text { (ceroid) }\end{array}$ & $\left|\begin{array}{c}1 \\
\text { (ceroid) }\end{array}\right|$ & \\
\hline
\end{tabular}

\section{Discussion}

Administration of sodium caseinate or sodium nucleate into mice was first adopted by Kuczynski (1923) ${ }^{1)}$ and then by Letterer $(1962)^{2)}$ as a procedure dfor the experimental production of amyloi. In the present experiments a ceroidlike pigment has been found developing in hypertrophied Kupffer's cells or histiocytes in mouse livers. Following subcutaneous administration of (I) sodium silicate, (II) sodium silicate plus prednisolone and (III) sodium nucleate plus prednisolone which has been adopted by Teilum for the purpose of producing amyloid. A comparative histochemical study has been made for this ceroid-like pigment with the ceroid pigment which has been obtained in the liver and other organs of mice of the same strain fed on a vitamin E deficient diet. Histochemically a ceroid-like pigment is featured by much less stainability in paraffin sections to basophilic dyes such as sudan III, methylgreen and toluidine blue than the ceroid pigment. However, this pigment demonstrates a marked similarity to the ceroid pigment in that it is acid fast fuchsin positive and chrome alum hematoxylin negative as primarily found in the ceroid pigment. Regarding the present experiments a ceroid-like pigment is exclusively found in the Kupffer's cell and histiocytes, while the ceroid pigment is observed as granules or rings in the liver cell and histiocytes as well as in the Kupffer's cell. A subsequent experiment has been carried out to make a comparative study between experimentally produced lipofuscin found in the rat liver and a ceroid-like pigment. As a result this experimentally produced lipofuscin is found to exist as fine granules in the cytoplasm of the hepatic cell, and as masses adjacent to the vascular wall of Glisson's capsule. This lipofuscin, being acid fast fuchsin negative and chrome alum hematoxylin strong positive and basophilic as well as being different in the developmental site, is to be clearly differentiated from a ceroid-like pigment. Histochemically a ceroid-like pigment seems to be between the ceroid pigment and lipofuscin. It is different from the ceroid pigment or lipofuscin on the basis of site and the mechanism of pigment formation. It must be admitted that a ceroid-like pigment obtained through an experimental method for the production of amyloid is quite different from amyloid regarding histochemical characteristics, morphology and developmental site. A ceroid-like pigment is congo red negative and is stained slightly blue, developing no metachromasia as amyloid on methyl violet staining. The present experimental groups showed an increase in glycogen in their alcohol fixed, paraffin sections. But no clear relations have been observed 
between the increase and the development of a ceroid-like pigment. Such an increase may be interested as a degenerative change, since it was observed concurrently with fatty degeneration in the liver of experimental animals as well as those reportred by Stowell et Lee $(1950)^{5}$.

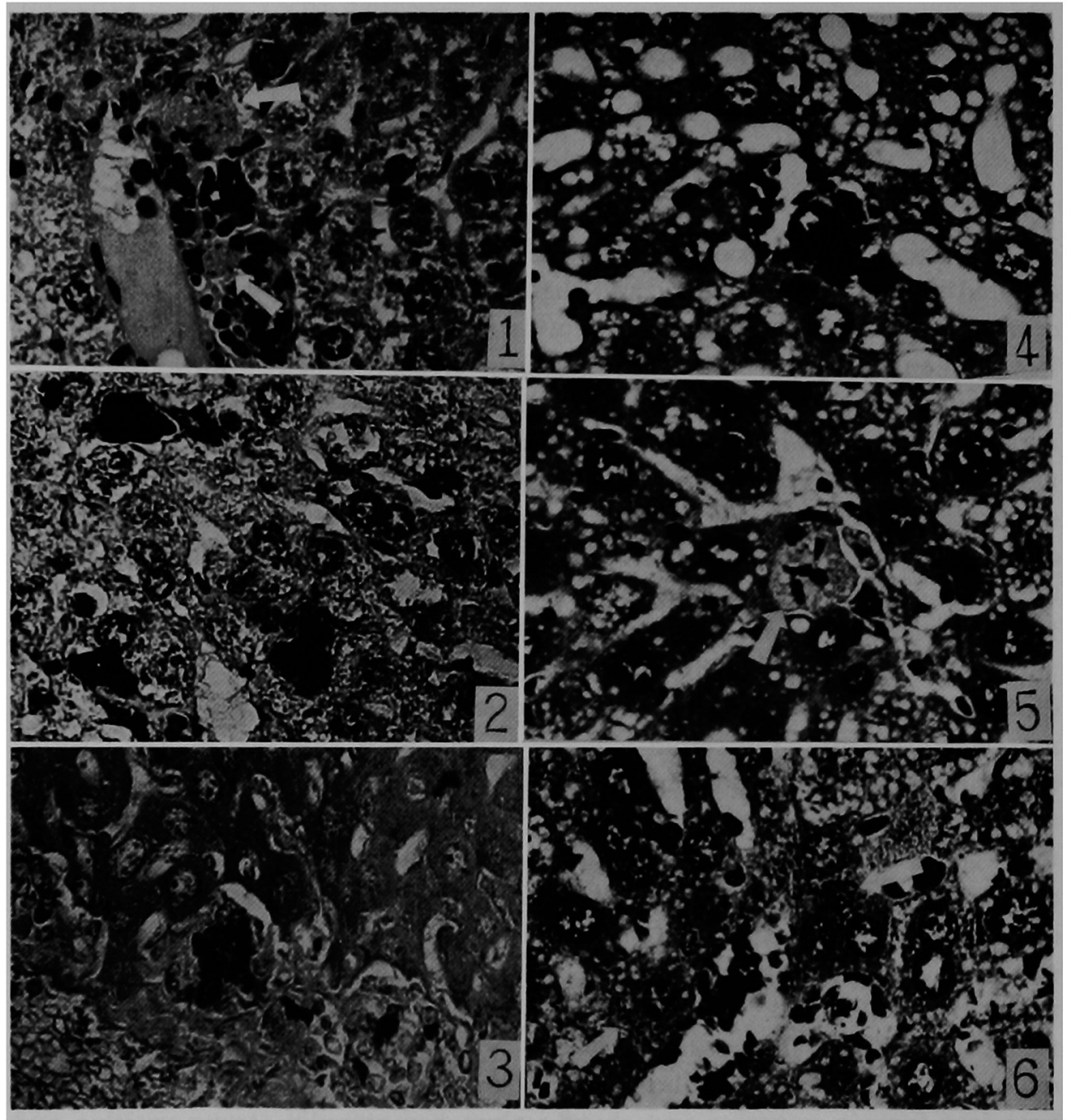

Fig. $1 \sim 6$

\section{Summary}

A ceroid-like pigment is observed in the Kupffer's cell and histiocytes of mouse liver following subcutaneous administration of sodium silicate, sodium silicate plus prednisolone and sodium nucleate plus prednisolone. Comparative histochemical studies are made between this ceroid-like pigment and the ceroid pigment experimentally produced in mice of the same strain which have been fed on a vitamin $\mathrm{E}$ deficient diet.

\section{References}

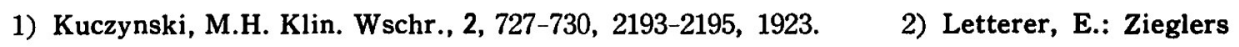


Beitr., 75, 486-588, 1926. Rep., 56, 1255-1258, 1941.
3) Lillie, R.D., Daft, F.S., and Sebrell, W.H.,: Pub. Health

4) Masson, K.E., and Emmel., A.F.: Anat. Rec., 92, 33-59, $1945 . \quad 5)$ Stowell, R.E., and Lee, C.S.,: Arch. Parth., 50, 519, $1950 . \quad$ 6) Tadaka, R. : Tr. Soc. Path. Jap., 49, 1035-1066, $1960 . \quad$ 7) Teilum, G. : Ann. Rheumat. Dis., 11, 119136, 1952.

\title{
Explanations of figures
}

The localization of a ceroid-like pigment and a lipofuscin is shown in figures 1-6, using formalin-fixed, paraffin sections of the liver of adult mice, divided into three experimental groups.

Fig. 1. Sections of group II which was subjected to subcutaneous administration of sodium silicate plus prednisolone. A coarsely globular yellow pigment, occurring in hypertrophied Kupffer cells or phagocytes. An arrow shows a ceroid-like pigment. Hematoxylin and eosin.

Fig. 2. Sections of group II. A ceroid-like pigment, being Sudan III-positive on formalinfixed, paraffin sections. Sudan III stain.

Fig. 3. Sections of group III which was subjected to subcutaneous administration of sodium nucleate plus prednisolone. A ceroid-like pigment, being acid fast fuchsin-positive. Acid fast fuchsin stain.

Fig. 4. Sections of adult mice, fed with vitamin $\mathrm{E}$ deficient diet for 134 days. The ceroid pigment which occurs in the Kupffer cell and liver cell, being shown to be acid fast fuchsin positive. Acid fast fuchsin stain.

Fig. 5. Sections of group III. A ceroid-like pigment, being chrome alum hematoxylin negative. An arrow shows the pigment. Chrome alum hematoxylin stain.

Fig. 6. Sections of adult rats in fasting for seven days. A number of fine granular lipofuscin which is chrome alum hematoxylin positive, being scattered in the cytoplasm of liver cells. An arrow shows a lipofuscin. Chrome alum hematoxylin stain.

\section{Distribution of Vitamin $A$ in the Liver}

\author{
Kenjiro WAKE \\ Department of Anatomy, Osaka City University Medical School, Osaka
}

It has been generally accepted that, if large amounts of vitamin $\mathrm{A}$ are given to animals, the excess of vitamin $A$ is stored in the Kupffer cells (reticulo-endothelial system) of the liver ${ }^{1,4,5,8)}$.

In this laboratory, during the course of histological, histochemical and electron microscopic studies on rat liver in hypervitaminosis A, it it clearly demonstrated that vitamin $A$ is not stored in the Kupfer cells, but in the transmittal cells ${ }^{6 \sim 9)}$ (interstitial cells) of the autonomic nervous periphery.

Albino rats (weight $150 \mathrm{~g}$ ) and rabbits (weight $2.5 \mathrm{~kg}$ ) were used in this study. Animals were injected subcutaneously with an excess of vitamin A acetate (Chocola A, EISAI, Tokyo). At periods of 1,2,3, and 4 weeks following injections animals were sacrificed by exsanguination. 